\title{
Safety implications of infotainment system use in naturalistic driving
}

\author{
Miguel A. Perez ${ }^{*}$ \\ Data Analysis Support Group, Virginia Tech Transportation Institute, 3500 Transportation Research Plaza, \\ Blacksburg, VA 24061, Unites States
}

\begin{abstract}
The use of a radio while driving has long been considered a "threshold" of distraction that is socially acceptable although it may be a factor in some crashes and near crashes. This "social acceptance" has prompted the use of radio tasks, specifically radio tuning, as "references" that should not be exceeded by other secondary and tertiary tasks that make their way into the vehicle. As new functions make their way into vehicle radios (or more advanced infotainment systems), however, it is possible that radio tasks may become distracting to a level that surpasses current driver expectations. This investigation examines the naturalistic usage of several advanced infotainment systems and examines whether usage is associated first with changes in near crash occurrence and second with changes in driving behavior. Little association was found with near crashes: 5 of 46 near crash events observed in the dataset exhibited infotainment system use. Drivers involved in infotainment system use during near crashes, however, did exhibit distinct glance behaviors, generally suggesting lower levels of awareness about their driving environment. Initial analyses of a larger dataset appear to confirm these findings.
\end{abstract}

Keywords: Radio, Infotainment System, Driver Distraction, Eye Glance, Event Detection

\section{Introduction}

The usage of a radio while driving has long been considered socially acceptable, even in current times where distraction has become a large area of focus (e.g., see [13] for a summary of efforts to measure distraction). For example, automotive interface design guidelines use radio tuning as a reference task in their suggested tests [6].

A potential concern, however, is whether radio usage, in its ever-changing context, remains a relatively low-risk activity to perform while driving. Or, in contrast, whether the larger video screens, the higher-information-density functions (e.g., iPod, satellite radio), and the larger number of controls being introduced in current production and aftermarket radios becoming a source of additional distraction that may increase crash risk. This investigation examined those issues by leveraging an existing smallscale naturalistic driving dataset documenting driver usage of high-functionality infotainment systems. Naturalistic driving databases have been used suc- fully in the past to establish links between distraction behaviors, crashes, and near crashes [8,9].

While radio usage tasks have been the subject of much research $[1,3,10,11]$, the information provided by these studies has been limited. Some studies have used laboratory settings, which reduce the applicability of the results. Other studies have tested technology that is now outdated, given the everchanging nature of infotainment systems.

This investigation examined how often drivers with access to an advanced infotainment system for about four weeks were involved in crash and near crash situations. This assessment included whether the use of the infotainment system was related to the crash or near crash event, and documentation of various driver behaviors. Of particular note is the implementation of a data coding protocol that documents the presence and detection of events, an important and often neglected element in driving distraction research $[1,2,7,12]$.

\footnotetext{
*E-mail: miperez@vtti.vt.edu; Ph: 1 (540) 231-1537; Fax: 1 (540) 231-1555.
} 


\section{Method}

The original study had 17 participants drive a vehicle equipped with a high-functionality infotainment system for a period of approximately 4 weeks. Participants used one of two different experimental vehicles as their own for this period of time. The vehicle was delivered to the participant at the beginning of the study and picked-up at the end of the 4-weekminimum participation period. Both vehicles were instrumented with aftermarket infotainment systems (Table 1). Throughout their involvement in the study, participants did not receive any instruction on the system nor were they provided with any information about the specific purpose of the study (i.e., to observe interactions with the infotainment system). Drivers did not receive any monetary compensation for participating in this study.

The vehicle was instrumented with a standardized data acquisition suite, based on the one used for the 100-Car study [4]. The data acquisition system collected audio (from the infotainment system), video, and driving performance data continuously, triggered on the ignition signal. The digital video was collected from four different video cameras positioned to show the driver's face, a view over the driver's shoulder, the forward driving scene, and a close-up view of the infotainment system. All four views were multiplexed into one video stream for later observation and analysis by trained reductionists.

Identification of potential crash and near crash events was achieved by overlaying the vehicle per- formance data against vehicle kinematics signatures described in [4]. Trained data analysts then watched the video for any potential crash and near crash events and assessed their validity. Valid events were then subjected to additional data coding that provided information about driver behaviors and eye glance patterns.

Eye glance coding, specifically, was completed for the duration of the kinematic trigger including 10 seconds before and 5 seconds after the start and end of the event, respectively. This additional reduction time allowed for the analysis of complete initial and final glances, and was otherwise excluded from analysis. The eye glance metrics that were analyzed included:

- Number of glances

- Average glance durations

- Total glance durations

- Glance rate

- Percent of glances based on frequency and duration

- Total eyes-off-road time

- $\quad$ Percent total eyes-off-road time

These measures were calculated by eye glance location and split into driving versus non-drivingrelated categorizations.

Given the relatively small dataset, results are presented mainly in terms of frequency counts. T-tests were used to assess statistically significant differences in eye glance patterns. Significance was detected using a Type I error of 0.05 .

Table 1

Experimental vehicles and infotainment systems

\begin{tabular}{|c|c|c|}
\hline Vehicle & Infotainment System & Features \\
\hline 2002 Cadillac STS & Clarion VRX755VD & $\begin{array}{ll}- & \text { Folding 7" color LCD touch-screen } \\
\text { - } & \text { AM/FM radio } \\
\text { - } & \text { CD/DVD/MP3 player (DVD image locked out when the vehicle was } \\
& \text { not in Parking gear) } \\
\text { - } & \text { Sirius } \\
\text { - } & \text { iPod receiver (satellite radio) } \\
& \text { to it and approximately } 80 \text { songs, was provided to each participant) } \\
\text { - } & \text { Steering wheel controls for volume and fader }\end{array}$ \\
\hline 2005 Ford Crown Victoria & Pioneer AVIC-N2 & $\begin{array}{ll}\text { - } & \text { Folding 7" color LCD touch-screen } \\
\text { - } & \text { AM/FM radio } \\
\text { - } & \text { CD/DVD/MP3 player; JPG picture reader (DVD playback locked out } \\
\text { when the emergency brake was not engaged) } \\
\text { - } \\
\text { - } \\
\text { iririus }{ }^{\mathrm{TM}} \text { receiver (satellite radio) } \\
\text { iPod interface (an iPod } \text { to }^{\mathrm{TM}} \text {, with the software necessary to add content } \\
\text { - Navigation System } \\
\text { O Map, favorite address entries, and the first screen of the points of } \\
\quad \text { interest were the only features active while the emergency brake } \\
\quad \text { was not engaged }\end{array}$ \\
\hline
\end{tabular}




\section{Results}

The analysis of potential crash and near crash events yielded no crashes and 46 near crashes. While there were a sizable number of triggers identified, relatively few were determined to be valid events (Table 2). Infotainment system use was a causal factor in a small proportion of events ( 3 out of the 46 cases; $6 \%$ ). Cell phone use as a causal factor was observed in 2 out of the 46 cases $(4 \%)$.

Table 2

Trigger analysis results

\begin{tabular}{lll}
\hline Trigger Type & Number of Triggers & $\begin{array}{l}\text { Determined to be } \\
\text { Valid }\end{array}$ \\
\hline $\begin{array}{l}\text { Button-Push } \\
\text { Longitudinal Dece- } \\
\text { leration }>0.4 \mathrm{~g}(>0.5 \\
\text { g) }\end{array}$ & $410(60)$ & 0 \\
$\begin{array}{l}\text { Lateral Accelera- } \\
\text { tion }>0.7 \mathrm{~g}\end{array}$ & 19 & $39(14)$ \\
$\begin{array}{l}\text { Low Forward TTC } \\
\text { Transient Yaw Rate }\end{array}$ & 10 & 0 \\
\hline
\end{tabular}

The reduction process classified the events into different categories, depending on the type of conflict that was observed (Table 3), for cases where infotainment system use was present and for cases in which it was absent.

Table 3

Frequency of different traffic conflicts observed as a function of infotainment use

\begin{tabular}{lll}
\hline Traffic Conflict & $\begin{array}{l}\text { Infotainment } \\
\text { Use Present }\end{array}$ & $\begin{array}{l}\text { Infotainment } \\
\text { Use Absent }\end{array}$ \\
\hline Animal Crossing & 1 \\
Braking to Turn & 1 \\
Lead Vehicle Backing & 1 \\
Lead Vehicle Decelerating & 2 & 18 \\
Lead Vehicle Incurring on Lane & 5 \\
Lead Vehicle Stopped & 3 \\
Left Turn Across Path (subject & 1 \\
$\quad$ driver) Traffic/Oncoming & \\
Oncoming Traffic Turning Across Path & 5 \\
$\quad$ & \\
Parking Lot & 1 \\
Passing on the Right & 1 \\
Pedestrian/Pedestrian Incurring & 3 \\
Single Vehicle & 3 & 1 \\
\hline
\end{tabular}

Events were also classified (Table 4) based on when the participant was glancing when the precipitating event occurred (if applicable), the extent to which the driver detected relevant objects on the forward roadway, the reaction time (if applicable), and the type of reaction. Note that the "Infotainment Use Absent" category included one event for which there was no forward roadway video. This event is not included in the table counts.

Table 4

Distribution of different descriptors of the driving situation across infotainment use

\begin{tabular}{|c|c|c|}
\hline Behavior & $\begin{array}{l}\text { Infotainment Use } \\
\text { Present }\end{array}$ & $\begin{array}{l}\text { Infotainment Use } \\
\text { Absent }\end{array}$ \\
\hline Forward Glance at & 3 Glancing / 2 Not & 29 Glancing / 11 \\
\hline Event Onset & Glancing & Not Glancing \\
\hline Driver Detection of & 1 All / 3 Some / 1 & 27 All / 11 Some / \\
\hline Relevant Events & No Events to & 1 None / 1 No \\
\hline $\begin{array}{l}\text { on the Forward } \\
\text { Roadway }\end{array}$ & Detect & Events to Detect \\
\hline Reaction Time & $\begin{array}{l}0.4 \text { sec, } \quad \mathrm{SD}=0.6 \\
(\mathrm{NS} *)\end{array}$ & $\begin{array}{l}1.1 \text { sec, } \quad S D=0.9 \\
\left(\mathrm{NS}^{*}\right)\end{array}$ \\
\hline Reaction Type & $\begin{array}{l}3 \text { Braking / } 2 \text { Not } \\
\text { Applicable }\end{array}$ & $\begin{array}{l}28 \text { Braking / } 8 \\
\text { Braking and Steer- } \\
\text { ing / } 3 \text { Steering / } 1 \\
\text { Not Applicable }\end{array}$ \\
\hline
\end{tabular}

T-tests found few significant differences in eye glance patterns (Table 5).

Table 5

Statistically significant eye glance measures

\begin{tabular}{|c|c|c|c|}
\hline $\begin{array}{l}\text { Eye Glance } \\
\text { Measure }\end{array}$ & $\begin{array}{l}\text { Infotainment } \\
\text { Use Present }\end{array}$ & $\begin{array}{l}\text { Infotainment } \\
\text { Use Absent }\end{array}$ & $p$-value \\
\hline $\begin{array}{l}\text { Glance Rate to } \\
\text { the Rear- } \\
\text { view Mir- } \\
\text { ror }\end{array}$ & $\begin{array}{l}0.0 \\
\text { (glances/min) }\end{array}$ & $\begin{array}{l}1.3 \\
\text { (glances/min) }\end{array}$ & $\mathrm{p}=0.013$ \\
\hline $\begin{array}{l}\text { Percent Num- } \\
\text { ber } \\
\text { Glances to } \\
\text { the Rear- } \\
\text { view Mir- } \\
\text { ror }\end{array}$ & $0.0 \%$ & $5.6 \%$ & $\mathrm{p}<0.01$ \\
\hline $\begin{array}{l}\text { Percent Num- } \\
\text { ber } \\
\text { Glances to } \\
\text { the Left } \\
\text { Mirror }\end{array}$ & $1.6 \%$ & $7.5 \%$ & $\mathrm{p}=0.030$ \\
\hline $\begin{array}{l}\text { Average Dura- } \\
\text { tion of } \\
\text { Glances } \\
\text { Forward }\end{array}$ & $2.7 \mathrm{sec}$ & $5.0 \mathrm{sec}$ & $\mathrm{p}<0.01$ \\
\hline $\begin{array}{l}\text { Average Dura- } \\
\text { tion of } \\
\text { Driving } \\
\text { Related } \\
\text { Glances }\end{array}$ & $2.7 \mathrm{sec}$ & $4.6 \mathrm{sec}$ & $\mathrm{p}=0.029$ \\
\hline
\end{tabular}




\section{Discussion}

The dataset yielded no crashes and a limited number of near crashes. While this limits the strength of the conclusions that can be gleaned from the data, it is not surprising given the relatively rare nature of these types of events. The "yield" of events from the triggers identified was also very low ( $\sim 3 \%$ overall) and in line with previous observations [5]. Future efforts should be directed towards developing event detection tools that are more sensitive and specific than those currently available. The use of artificial intelligence techniques (e.g., artificial neural networks) may aid in such efforts in the future.

Infotainment system or cell phone use was observed on about $10 \%$ of the near crash events in the dataset. While low, the number is not trivial, since the percentage of time that participants spent manipulating system controls across the entire dataset was approximately $2 \%$. Therefore, there seems to be a nominal over-representation of infotainment system manipulations in near crash events. Larger datasets are needed to assess the actual presence and magnitude of this effect. Nominally, infotainment system or cell phone use was also over-represented in "Single Vehicle" traffic conflicts (e.g., lane excursions).

The forward glance at event onset data are particularly interesting, because they provide a glimpse into the event detection area. Participants were glancing away from the forward roadway on $\sim 28 \%$ of cases, but failed to see all the relevant events on $\sim 35 \%$ of the events. Therefore, there is some potential (albeit small) evidence of "looking but not seeing."

In terms of driver reaction to near crash conditions, braking was the most common reaction to these events $(\sim 84 \%)$, either by itself or in combination with steering. While the reaction times were not significantly different between infotainment use presence and absence, it is interesting that they were nominally lower when infotainment system use was present. There was no assessment of near crash event severity, but perhaps those near crashes where infotainment system use was present were more severe and required a quicker response.

Statistically significant results were observed in only a small number of eye glance metrics. Seen as a whole, the data suggest that there was definitely some visual demand placed on the participants when they interacted with infotainment systems. This demand was met at the expense of peripheral glances that arguably improve the participant's situation awareness (e.g., glances to the rear view mirror) and at the expense of longer glance durations to the forward roadway. Ongoing analyses of further data show how these infotainment system tasks demand these glances, with clear differences shown between baseline conditions and different infotainment system tasks (Figure 1).

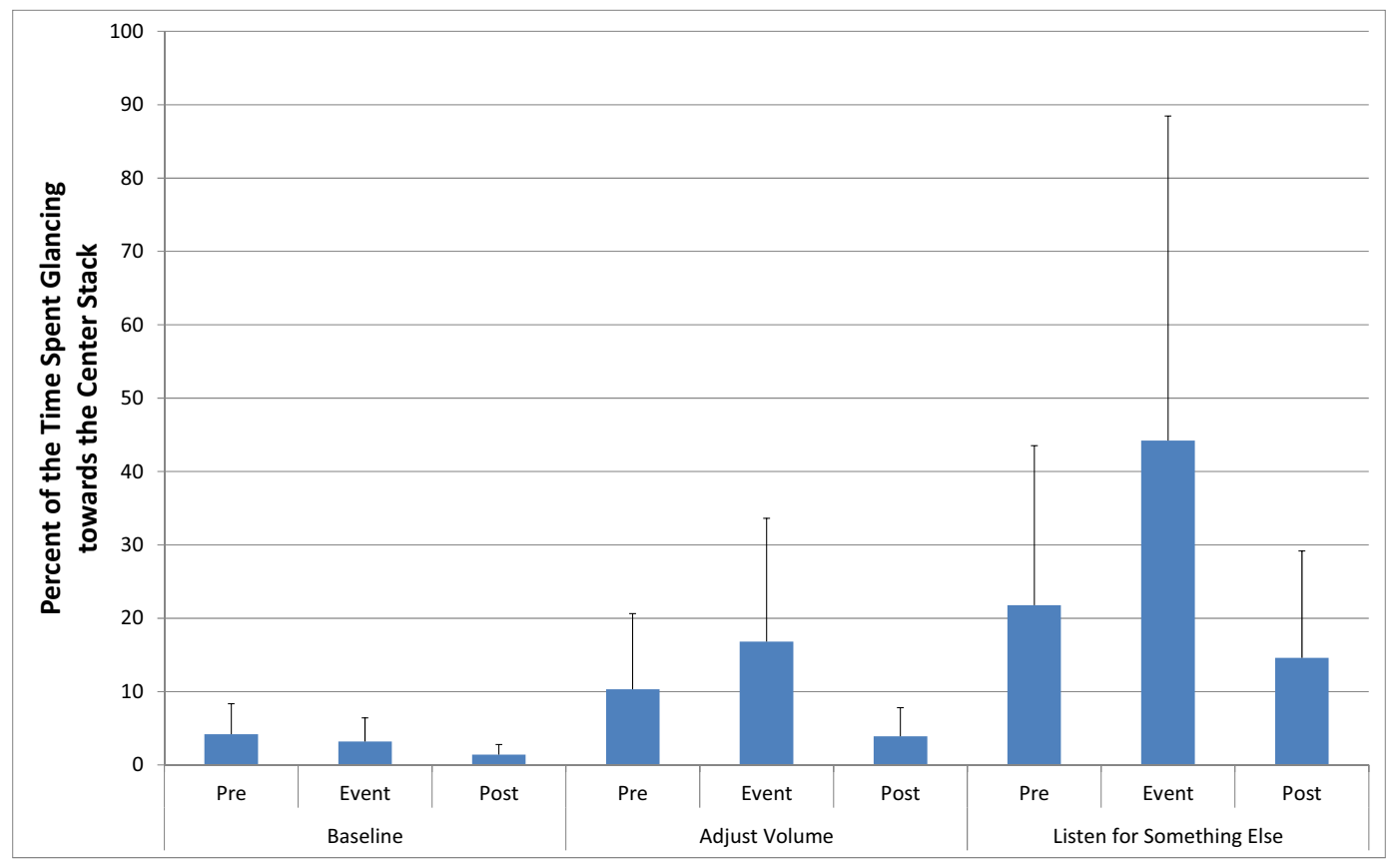

Fig. 1

Percent of the time spent glancing towards the center stack as a function of the type of infotainment task and the timing of the observation (pretask, during the task, post-task) 
Overall, the advanced infotainment systems studied in this dataset were present in some near crashes, but their presence was not pervasive. Larger datasets are needed to fully assess whether the slight overrepresentation of infotainment system use that was nominally observed is indeed a general finding. Even if such an over-representation does not exist, there are observable adjustments in eye glance patterns that could place drivers at increased crash risk when operating these devices. An overrepresentation of infotainment system use in crashes and near crashes would yield hypothetical ties between these adjustments and crash risk. The opposite finding may be indicative of driver self-regulation in the use of these devices (e.g., using them in low traffic density situations). Future work will continue to examine these issues.

\section{Acknowledgments}

This work was sponsored by Surface Transportation Safety Center of Excellence at the Virginia Tech Transportation Institute. The opinions, findings, and conclusions expressed in this publication are those of the authors and not necessarily those of the sponsor.

\section{References}

[1] Angell, L., et al., Driver workload metrics. Task 2 final report, 2006, National Highway Traffic Safety Administration: Washington, D.C.

[2] Angell, L.S., Conceptualizing effects of secondary task demands on event detection during driving: Surrogate methods and issues, in Performance metrics for assessing driver distraction: The quest for improved road safety, G.L. Rupp, Editor 2010, SAE International: Warrendale, PA. p. 42-71.

[3] Curry, D.G. and T. Jaworski. Frequency of use of automotive stereo controls. in Proceedings of the Human Factors and
Ergonomics Society 42nd Annual Meeting. 1998. Chicago, IL: The Human Factors and Ergonomics Society, Santa Monica, California.

[4] Dingus, T.A., et al., The 100 car naturalistic driving study, phase II - Results of the 100 car field experiment, 2006, National Highway Traffic Safety Administration: Washington, D.C.

[5] Dingus, T.A., et al., The development of a naturalistic data collection system to perform critical incident analysis: An investigation of safety and fatigue issues in long-haul trucking. Accident Analysis and Prevention, 2006. 38(6): p. 1127-1136.

[6] Driver Focus-Telematics Working Group, Statement of principles, criteria and verification procedures on driver interactions with advanced in-vehicle information and communication systems, 2006, Alliance of Automobile Manufacturers: Washington, D.C. p. 90.

[7] Greenberg, J., et al., Driver distraction: Evaluation with event detection paradigm. Transportation Research Record, 2003. 1843: p. $1-9$

[8] Klauer, S.G., et al., The impact of driver inattention on nearcrash/crash risk: An analysis using the 100-Car naturalistic driving study data, 2006, National Highway Traffic Safety Administration: Washington, D.C. p. 224.

[9] Klauer, S.G., et al., An analysis of driver inattention using a case-crossover approach on 100-Car data: Final report, 2010, National Highway Traffic Safety Administration: Washington, D.C. p. 148.

[10] Nes, F.L.v. and J.P.M.v. Itegem, Hidden functionality: How an advanced car radio is really used, 1990, Institute for Perception Research: Eindhoven, The Netherlands. p. 101112.

[11] Neurauter, M.L., J.M. Hankey, and R.A. Young. Radio usage: Observations from the 100-Car naturalistic driving study; SAE Technical Paper No. 2007-01-0441. in SAE 2007 World Congress. 2007. Detroit, MI: Society of Automotive Engineers.

[12] Reyes, M.L. and J.D. Lee, Effects of cognitive load presence and duration on driver eye movements and event detection performance. Transportation Research Part F-Traffic Psychology and Behaviour, 2008. 11: p. 391-402.

[13] Rupp, G.L., 4th international driver metrics workshop: Summary and next steps, in Performance metrics for assessing driver distraction: The quest for improved road safety, G.L. Rupp, Editor 2010, SAE International: Warrendale, PA. p. 254-263. 